\title{
THE IMPACT OF LANGUAGE ON BUILDING THE INTERNAL MARKET: THE CONSUMER TRANSACTIONS PERSPECTIVE
}

\author{
OSKAR FILIPOWSKI*
}

\section{INTRODUCTION}

On 25 October 2011, after 3 years of negotiations, the European Parliament and the EU Council published a new directive on consumer rights ${ }^{1}$ that must be implemented into Member States' legal systems by 13 June 2014. The scope of the new rules will cover nearly all types of sales contracts including those concluded in shops, via phone, catalogue sales as well as "doorstep" sales. The new catalogue of customer rights ${ }^{2}$, as emphasized by the EU officials $^{3}$, will focus on consumers' rights in business to consumer (B2C)

DOI: $10.1515 /$ wrlae-2015-0002

* dr Oskar Filipowski - University of Wrocław Faculty of Law, Administration and Economics, Institute of Administrative Law, solicitor; contact at oskar.filipowski@prawo.uni.wroc.pl

${ }^{1}$ Council Directive 2011/83/EU of 25 October 2011 on consumer rights, amending Council Directive 93/13/EEC and Directive 1999/44/EC of the European Parliament and of the Council and repealing Council Directive 85/577/EEC and Directive 97/7/EC of the European Parliament and of the Council [2011] OJ L 304/64.

${ }^{2}$ According to an EU Press Release from 23 June 2010 (MEMO/11/450) the new directive focus on 10 major points that are to strengthen consumers' rights. The catalogue includes following points: 1) Elimination of hidden charges and costs on the Internet; 2) Increased price transparency; 3) Banning pre-ticked boxes on websites; 4) 14 days to withdraw from a sales contract; 5) Better refund rights; 6) Introduction of an EU-wide model withdrawal form; 7) Eliminating surcharges for the use of credit cards and hotlines; 8) Clearer information on who pays for returning goods; 9) Better consumer protection in relation to digital products; 10) Introduction of common rules for businesses to allow trade all over EU.

${ }^{3}$ For example, Vivane Reading, Vice-President of the EC responsible for Justice, Fundamental Rights and Citizenship made it very clear during her speech during European Consumers' Day, 15th March 2010 in Madrid. She said: "We live in a Single Market of more than 500 million consumers. But when you go online and try to shop, you wouldn't realise it. Those 500 million consumers are some of the most tech-savvy, innovation-hungry consumers in the world. But at the moment, the Single Market is letting them down, especially when they go online. [...] Until 
transactions online. According to the Directive's preamble ${ }^{4}$, the new rules will result in enhanced trust of customers and encourage entrepreneurs to complete more cross-border sales. This way the European lawmakers want to achieve several goals. First of all, the main objective is to strengthen the internal market by boosting internal demand that could emerge as a result of cross-border transactions. Secondly, the aim is to enhance competition within the internal market that could allow the achievement of greater economic efficiency (allocative efficiency). It should also help European market champions (capable of competing with large companies from other parts of the world ${ }^{5}$ ) to emerge.

To achieve these objectives, the European Commission (EC) has focused on online sales, where there remains massive room for improvement. According to official statistics the EU market consists of more than 500 million consumers $^{6}$. In 2010, 37\% of all EU consumers made a distance purchase on the Internet ${ }^{7}, 21 \%$ used the post (catalogues, mail order, etc.) and $13 \%$ made a distance purchase via phone ${ }^{8}$. This means that more than $50 \%$ of all EU consumers made some kind of distance purchase in 2010. However, only $7 \%$ of them decided to make a cross-border transaction. Spending levels were also very low, as more than seven out of ten of the above mentioned transactions were for less than $€ 500$. Such a situation shows that this market has very good potential for development which can be explored to the benefit of the whole EU economy.

However, the question must be asked if this expected boost to crossborder online sales is possible at all. In my opinion there is one large obstacle that may hinder this process (leaving aside transportation costs that may apply to traditional goods): language. First of all, language may cause problems at the level of transactions themselves, and secondly the implementation of Directive 2011/83/EU raises concerns over the convergence of legal languages in the EU. These two potential sources of difficulties will be examined in the following sections of this paper.

\section{LANGUAGE IN CONSUMER TRANSACTIONS}

Language is an issue that has a significant impact on both sides of the transaction, the customer and the entrepreneur. Sometimes it can be a decisive factor in concluding a contract. On the one hand, if a customer does not feel

consumers feel that their rights are protected when they shop across borders, they will limit their purchases to their own countries and won't take advantage of the EU's crown jewel - the Single Market" - whole speech available at $<$ http://europa.eu/rapid/press-release_SPEECH-1091_en.htm> accessed 10 September 2013.

${ }^{4}$ See Rec. 7 Council Directive 2011/83/EU.

5 The same argument is made by Piet Jan Slot, 'A View from the Mountain: 40 Years of Development in EC Competition Law' (2004) 41 CMLRev. 445-446.

${ }^{6}$ See EC Study, Consumer attitudes towards cross-border trade and consumer protection. Analytical report (Brussels 2011) 5.

${ }^{7}$ It is worth mentioning that this number is gradually rising each year.

${ }^{8}$ See Slot (n 5). 
comfortable with the language used in a transaction, he may decide not to enter into a contract. On the other hand, the use of multiple languages by a commercial entity may increase transaction costs and thus make the seller less competitive. For these reasons multiple aspects of every transaction have to be considered.

Let us take the example of a simple transaction involving the sale of an mp4 player from Italy to Poland. It raises issues of a legal and a business nature that must be addressed by entrepreneurs. Which language should be used to conclude this transaction? Can the guarantee terms be given in Italian or English? Which terminology should be applied within a given language ${ }^{9}$ and what style should be used? Will consumers always expect to negotiate in their native language? This example shows clearly that cross-border consumer sales are far more complex than offer and acceptance, transport, and payment of the price. They involve language choices that sometimes are stipulated by legal provisions which are not always associated with consumer law ${ }^{10}$.

However, it can be said that those issues are inseparably connected with knowledge of foreign languages in the EU that enable cross-border communication. According to the Eurobarometer survey from $2005^{11}$, more than $50 \%$ of EU citizens claimed the ability to have a conversation in at least one language other than their mother tongue. However, those percentages vary between countries and social groups ${ }^{12}$. Of importance from the consumers' point of view is that young people aged 14-24 demonstrate the best knowledge of foreign languages out of all age groups, with the ability to use a foreign language decreasing with age. These statistics clearly indicate that the

${ }^{9}$ It may be a question of the use of terminology from a given legal system or from several systems that use the same language.

${ }^{10}$ For example, in Poland Art. 7a(1) of the Polish Language Act (Journal of Laws 2011, no 43, item 224) stipulates that the names of goods and services, terms of guarantees, bills, manuals and warnings shall be given in Polish. Art. 7 of the cited act establishes that the above listed documents shall be given to every consumer that has his place of residence in the territory of Poland. To understand the term "residence" it is necessary to refer to Art. 25 of the Polish Civil Code which defines it as the place where a natural person stays with an intention to permanently reside. Now let us consider this from the entrepreneur's point of view. He is supposed to study all 27 Member State legal systems and then prepare documents according to those laws. Alternatively, he can prepare documents in all of the EU official languages. In both cases transaction costs are increased and big market players have an advantage.

${ }^{11}$ Special Eurobarometer Wave Europeans and languages $<$ http://ec.europa.eu/public_opinion/archives/ebs/ebs_237.en.pdf $>$ accessed 10 August 2013. All Eurobarometer statistics quoted in this section come from this survey.

12 99\% of Luxembourgers, $93 \%$ of Latvians and Maltese, and $90 \%$ of Lithuanians know at least one language other than their mother tongue, whereas a considerable majority in Hungary (71\%), the UK (70\%), Spain, Italy, and Portugal (64\% each) only speak their mother tongue. Men, young people, and residents of cities are more likely to speak a foreign language than women, senior citizens and those living in rural areas. The most widely-known foreign language in the EU is English (34\%), followed by German (12\%) and French (11\%). 
knowledge of languages within the EU society will rise every single year. However, it should be noted that the survey examined the knowledge of everyday language, not legal language. This means that probably only a very limited number of people can understand legal documents in a foreign language.

Nevertheless, it can be argued that consumers do not need to have a throughout knowledge of a foreign language to conclude a transaction. From the average consumer's point of view it is important to received what has been ordered (or what the consumer wished to order to be more precise), and that it is clear how to use the purchased good and what to do when something goes wrong. Consumers are now supported by a wide range of modern technology: web browsers and search engines allow them to find web pages in foreign languages by translating given key words into a different language, and translators enable translation of the content of a web page into a consumer's mother tongue ${ }^{13}$. Consumers may use these tools to check the availability of goods and services they wish to purchase. Also, most web pages have an English version, allowing more than one in three EU citizens to understand it without resorting to technical means of translation. The second issue of understandable manuals has already been dealt with by the market itself. Most producers provide multi-language manuals in most of the official EU languages or using pictograms that are understood worldwide and do not have to be translated $^{14}$. However, the most vital issue is the third one, which involves how to proceed when the transaction or the purchased good turns out to be faulty.

As far as the financial part of a transaction is concerned, using credit and debit cards as well as special payment systems such as PayPal or Dotpay gives a higher level of certainty as it helps in making a successful refund claim $^{15}$. However, if a consumer wants to return a product or use the included guarantee, this may be problematic as most people are afraid that not knowing a foreign legal system and local rules on distance purchasing will stop them from submitting a successful claim. For this reason, in my opinion, rules governing return periods and complaint procedures for consumers should be harmonized and kept simple, so that everyone can understand them ${ }^{16}$. The new Directive

\footnotetext{
${ }^{13}$ Of course, one may say that the quality of the translation is poor. This is obviously true, but it gives at least a vague idea of the web page's content. Most of the goods sold on the Internet are standardized. It means that we can obtain information about them in other languages, including our mother tongue. Moreover, the technology of automatic translations has improved considerably in recent years, and will improve even more in the future, giving consumers a more detailed understanding of the content of web pages.

${ }^{14}$ Such pictograms are used for example with clothes or car dashboards.

${ }^{15}$ Stability and protection of customers in such transactions is also guaranteed by Council Directive 2002/65/EC of 23 September 2002 concerning the distance marketing of consumer financial services and amending Council Directive 90/619/EEC and Directives 97/7/EC and 98/27/EC [2002] OJ L 271/16.

${ }^{16}$ According to a paper by the Polish Office of Competition and Consumer Protection titled Customers' self-portrait (UOKiK 2007) 37 only 13 per cent of all consumers know the return period for goods and services obtained via the Internet, and only $0.03 \%$ are able to correctly name the claim period for goods inconsistent with the terms of the contract. For this reason, not
} 
2011/83/EU is a positive step towards these postulates as it gives consumers a 14-day return period as well as provides an optional withdrawal form that can be used by consumers. However, the language in which the form should be completed is not stipulated.

When the provisions discussed above are ensured, consumers will likely be encouraged to engage in cross-border online transactions ${ }^{17}$. However, it is also important to understand the sellers' point of view. If the transaction costs of conducting a cross border sale are considerably higher than those associated with other types of business activities, they will be discouraged to get involved in the more costly business. Fortunately, in this case standardization of complaint procedures also facilitates reducing the costs of its consideration.

This idea can be summarized by saying that the most important issue in the seller-buyer relationship during cross-border online transactions is mutual understanding that leads to trust. If EU regulations are able to convince consumers that they will be able to successfully pursue a claim in another country, and in the meantime the EU legislator does not shift all of the costs onto the entrepreneurs, cross-border trade could develop as expected. However, it is important to bear in mind that these rules must be kept simple, so that they are understood by the average customer with a limited knowledge of the law ${ }^{18}$. When demand is present, supply will follow. The market will find a way to overcome language obstacles by using graphics, translators, etc. For this reason the task of the EU legislator is to focus on building trust so that parties can achieve mutual understanding during cross-border transitions.

When considering consumers, it is crucial to ensure that they uniform rights that can be materialized in the same way in all EU Member States. The provisions of Directive 2011/83/EU ${ }^{19}$ should be judged positively in light of the aforementioned. However, the author fears that such guarantees may not be enough, for reasons to be presented in the of this paper. A solution that may also overcome legal linguistic issues will be presented.

only is harmonization necessary, but also education, as consumers in post-Soviet bloc countries are less aware of their rights than their counterparts in the so-called old EU.

17 Another question that needs to be asked is if it will be due to the directive, or to generally higher computer literacy and better foreign language skills. In my personal opinion, it will be a mix of both. The role of the EU is to ensure that this potential is not wasted.

${ }^{18}$ In this case, the average level of legal knowledge across the EU should be determined taking into consideration the societies of countries with low levels of consumer awareness. Adopting other standards may lead to discrimination and social exclusion, and thus could be seen as contrary to the EU's legal principles.

${ }^{19}$ See EU Press Release (n 2). 


\section{LEGAL LANGUAGE IN CONSUMER LAW}

Addressing the second issue mentioned at the beginning of this article, it must be said that the problem of different legal languages functioning in one country is not new. Such a situation can be observed in such countries as Canada, Belgium, Switzerland and Finland. However, none of those are comparable in scale with the situation in the EU as a whole. The twenty-eight Member States of the European Union have twenty-four official languages among them, not to mention local languages such as Welsh and Catalonian. It is extremely difficult to draft legal texts for European law, especially if they are also supposed to be understood by consumers, as the majority of them do not even understand the legal language of their own motherland very well. Moreover, more languages mean more translations, and more translations mean more staff and a more profound impact of interpretation on the $l^{20}{ }^{20}$. When adding to that the fact that no two translators would produce an identical translation, this shows how complex the issue is. This situation may give rise to the fear that the construction of an internal market for consumer transactions may end in the same way as the biblical construction of the tower of Babel.

To determine whether such fears are justified, an analysis of the most important problems concerning legal language has to be made. These issues will be catalogued and described, and I will also propose solutions to them.

\section{a) Different definitions used in different directives}

The problem of defining a given term in different ways in separate acts is one that occurs frequently. It does not come up in consumer law alone or solely at the level of EU Directives, but is also a common issue for the legislation of Member States. For example, in the Polish legal system, the notion of a concession (koncesja) is associated with permission to conduct economic activity granted by the state ${ }^{21}$, as well as a particular kind of public contract, such as in the field of public infrastructure investments ${ }^{22}$. A similar issue was raised in consumer Directives in the past. For instance, in Art. 1(2) of the Consumer Sales Directive ${ }^{23}$ a consumer was described as "a natural person who, (...), is acting for purposes which are outside his trade, business or profession." In other Directives a different definition is given. In the doorstepselling Directive ${ }^{24}$, a consumer is defined as "a natural person who, $(\ldots)$, is acting for purposes which can be regarded as outside his trade or profession" (Art. 2) and the Price Indication Directive defines a consumer as a "natural person who buys a product for purposes that do not fall within the sphere of his commercial or professional capacity" (Art. 2(e)). Furthermore, according to Art.

\footnotetext{
${ }^{20}$ See Viola Heutger, 'More Coherent European Wide Legal Language' (2004) 8 (2) EIoP, $<$ http://ssrn.com/abstract $=520742>$ accessed 10 September 2013.

${ }^{21}$ Art. 46 of the Economic Activity Freedom Act (Journal of Laws 2010, no 220, item 1447).

${ }^{22}$ Art. 1(2) of the Concession for Construction Works and Other Services Act (Journal of Laws, no 19 , item 101).

${ }^{23}$ Council Directive 1999/44/EC of 25 May 1999 on certain aspects of the sale of consumer goods and associated guarantees [1999] OJ L 171/12.

${ }^{24}$ Council Directive 85/577/EEC of 20 December 1985 to protect the consumer in respect of contracts negotiated away from business premises [1985] OJ L 372/33.
} 
1(a) of the Unfair Commercial Practices Directive ${ }^{25}$ a consumer is "any natural person who, in commercial practices covered by this Directive, is acting for purposes which are outside his trade, business, craft or profession."

Although the argument may be raised that this issue is not a consumerspecific one as it can be observed in every legal area, in this case it should be perceived differently. It is often forgotten that such a diversity of definitions will be understood by lawyers, but could cause confusion among consumers, who would not know when the law is applicable to them and when it is not ${ }^{26}$.

The problem under discussion is not purely academic, as there are some important differences in understanding of the consumer notion in the EU Member States. There is no controversy over the fact that under the aforementioned directives only natural persons are regarded as consumers, as this has been declared expressly at the European level in joined cases C-541/99 and C-542/99 - Idealservice ${ }^{27}$. However, the picture becomes muddied when we examine the issue of mixed-purpose transactions ${ }^{28}$. Even though the CJEU addressed this problem in its C-464/01 - Gruber ${ }^{29}$ judgment (concerning Art. 9 of Directive $85 / 374 / \mathrm{EC}$ ), the Court's ruling brought no clarification on this issue. This led to Member States finding different solutions for classifying mixed-purpose transactions ${ }^{30}$. Some countries do not hold such contracts to be customer ones (Austria, Belgium), but most classify them as such depending on whether private or business considerations are the predominant consideration driving the purchase of goods or services ${ }^{31}$.

Such diversity in the notion of a consumer may undermine trust in the market, as consumers may be confused in respect of their status. There is a significant possibility that they will decide to avoid uncertainty, which will lead to slower growth in cross-border consumer transaction volume. However, in my opinion, it is not the simple fact of divergence in the definitions of Member States as to what constitutes a consumer that is responsible for reduced trust,

${ }^{25}$ Directive 2005/29/EC of 11 May 2005 concerning unfair business-to-consumer commercial practices in the internal market and amending Directives 84/450/EEC, 97/7/EC, 98/27/EC and 2002/65/EC and Regulation (EC) No 2006/2004 [2005] OJ L 149/22.

${ }^{26}$ It cannot be forgotten that some suppliers may also try to cause confusion on purpose to deprive customers of their rights. This can be a serious issue as according to the cited Customers' self-portrait report, more than $30 \%$ of Poles trust that the seller knows the law better than they do.

${ }^{27}$ CJEU judgment of 22 November 2001, joined cases C-541/99 and C-542/99 Cape Snc $v$ Idealservice Srl and Idealservice MN RE Sas v OMAI Srl [2001] ECR I-9049, para 16.

${ }^{28}$ Such situation occurs when contracts serve both a private and business purpose (e.g. the acquisition of a motorbike for a freelancer).

${ }^{29}$ CJEU judgment of 20 January 2005, C-464/01 Johann Gruber v Bay Wa AG [2005] ECR I00439 .

${ }^{30}$ For more see Martin Ebers, "The notion of "consumer"' in Hans Schulte-Nölke (ed), EC Consumer Law Compendium - Comparative Analysis (Sellier 2007) 728.

${ }^{31}$ ibid. 
but rather the opaque requirements of EU law that allow for different approaches in various Member States.

This situation may be addressed in two ways. Firstly, we can wait for the CJEU to resolve all uncertainties regarding the elements of the consumer notion. However, this may take a long time and may constitute an obstacle in the virtual environment, where changes occur on a day-to-day basis. It must also be remembered that during this period some customers may become "victims" of this divergence, which will discourage them to engage in future cross-border trade.

The second response is to implement a universal definition of the notion of the consumer. The new Directive 2011/83/EU seems to tackle this problem at least partially by introducing a new definition that should replace those in Directives 93/13/EEC, 1999/44/EC and 97/7/EC. However, it does not address the other Directives mentioned above. Moreover, this solution also leads to further problems, as the same category of customers must be protected by every Directive enacted by the EC. Nevertheless, this approach would seem to bring those laws closer to consumers (even in countries where legal awareness is low), creating simplicity and fostering the trust needed to commence crossborder sales transactions ${ }^{32}$.

However, even a unified definition cannot fully address the issue, as other linguistic obstacles to be discussed are present.

b) The same word has different meanings in the same language

The implementation of Directives involves a broad range of linguistic interpretations even within the same language. This is for example the case with the Austrian and German legal systems, which use different definitions for the same legal term. For example: "Begriff der Sache" (notion of goods) § 90 BGB (German Civil Code) "Sachen im Sinne des Gesetzes sind nur körperliche Gegenstände",33, and $§ 285$ ABGB (Austrian Civil Code): "Alles, was von der Person unterschieden ist, und zum Gebrauche der Menschen dient, wird im rechtlichen Sinne eine Sache genannt."34 This is just one of many examples that clearly show how parties to a contract from different countries may have something different in mind while reading the same contract. For this reason, EU lawmakers should avoid situations involving the use of legal terms specific to a particular national code.

Language divergence can also be created by a translation itself. For example, the term "goods" can be translated into Polish in at least three different ways 35 . In German it can be translated as "Waren" or "Güter". The actual terms used in translation can have a huge impact on the legal result, as those terms will be associated with different objects in national legislation. For this reason it can be said that language issues might thwart the full

32 The argument of simplicity was very well expressed by Robert Stefanicki, Ochrona konsumenta $w$ świetle ustawy o szczególnych warunkach sprzedaży konsumenckiej (Wolters Kluwer Polska 2006) 78-80.

33 "Only physical objects are goods within the meaning of the Act" - (translation by the author).

34 "Everything that is distinct from a person and serves a human use is called goods in the legal sense" - (translation by the author).

${ }^{35}$ These terms are towary (things), ruchomości (movables), dorobek (possessions). 
harmonization process initiated by the European legislator with Consumer Directive 2011/83/EU.

A couple of possible solutions to this issue have been offered. The first, proposed by V. Heutger, involves the creation of an EU language policy ${ }^{36}$. According to V. Heutger, legislation should be drafted by an academic network under the guidance of the EC. Such a document should provide definitions of terms and concepts for sector-specific use in order to help in ensuring uniform and coherent use of language. She also proposes using at least three different legislators from different legal backgrounds. These measures should be followed by the proper education of lawyers in foreign languages. In my view, this process could not only take years, but may prove ultimately futile. For example, it would not persuade Germans and Austrians to unify their legal languages. It would not eliminate the possibility of mistranslations, but it would at least make it more likely that the proper one will be chosen.

In my opinion there is only one way to fully harmonize consumer law in EU, which I will describe below. As I have already demonstrated, lawmakers at the EU level as well as in Member States are faced with multiple language problems that are accompanied by often ambiguous terms in the EU's own legal language. However, such issues exist not only in consumer law, but also in other legal areas. For example, language convergence and clarity is a key issue in the financial sector, where banks may try to evade EU regulation by exploiting the uncertainty surrounding terms used in directives, or by improperly implementing directives ${ }^{37}$. In this case, I argue that the solutions used in this sector (while having different motivation) could be also transposed to consumer transactions legislation.

The discussed solution requires the use of directives that would be accompanied by regulations containing technical information (e.g. requirements for complaint form), as well as definitions of key terms. Such a system was

\footnotetext{
${ }^{36}$ Viola Heutger, 'Legal Language and the Process of Drafting the Principles on a European Law of Sales' (2008) 12 Electronic Journal of Comparative Law 13, $<$ http://www.ejcl.org/122/art122-3.pdf $>$ accessed 10 September 2013.

${ }^{37}$ Such a situation may occur due to the fact that a given directive was not properly understood or was not properly translated, as is often the case in countries that do not contribute proper resources towards implementation activities. It should be noted that the territorial expansion of the EU is resulting in the addition of new countries that have no experience in the use of acquis communautaire, which may lead to cracks in the EU system.
} 
introduced during the MiFID revision ${ }^{38}$ and was implemented in other legislative processes such as during revision of the market abuse regime ${ }^{39}$.

The reason why this solution is necessary is that directives have to be implemented within the legal systems of each Member State. Therefore, they are interpreted using definitions proper for national laws ${ }^{40}$ that create a mosaic of similar yet not identical systems. The use of regulations will help to tackle this problem. As regulations do not require transposition and are directly in force in all Member States, all the terms used in them will be unified, and they will belong to a newly-created specific EU language. This way consumers and entrepreneurs will be able to identify their rights and duties in one simple act rather than searching for them in different places ${ }^{41}$ in individual legal systems. This will keep things simple and will eliminate many language problems, as certain terms will have to be defined according to the interpretation given in judgments by the CJEU. Of course, I am also fully aware that this solution has its drawbacks. One major issue concerns the compliance of using regulations in this way with the subsidiary principle enacted in Art. 2 and Art. 4(2) TFEU ${ }^{42}$. Critics may say that the use of regulations goes too far, as directives can achieve the same goal. Apart from that, the use of regulations may limit the sovereignty of Member States. In my opinion these arguments are off the mark. First of all, as the Market Abuse Directive ${ }^{43}$ reform shows it is possible that a Directive alone may not be a sufficient tool to achieve the desired effects. In the case under examination here, the goal of EU lawmakers is to create an internal market for consumers with standardized rules that will encourage them to enter into cross-border online transactions. In other words, the goal could be redefined as the creation of a common protection system for all consumers. In order to achieve this objective, it is necessary to impose the same rules on every single Member State. Directives cannot do that as they are "reshaped" by the implementation process. Only regulations can create a unified system, ensuring interpretative convergence and therefore creating trust among consumers and

\footnotetext{
${ }^{38}$ Markets in Financial Instruments Directive (MiFID) is a key instrument in regulating the European financial market. In October 2011 the EC decided to revise this Directive. The proposal includes the new Directive as well as the new Regulation. For more see $<$ http://ec.europa.eu/commission 20102014/barnier/headlines/news/2011/10/20111020 en.htm> accessed 10 September 2013.

${ }^{39}$ In this case EU legislator prepared a revision of Council Directive 2003/6/EC (Market Abuse Directive) that consists of a new Market Abuse Directive proposing minimal criminal sanctions for market manipulation, and a Market Abuse Regulation that handles the issue of national and European regulators' competences, scope, exemptions as well as behaviors considered market manipulation, the definition of inside information and conditions of its disclosure. The Directive itself redirects readers to the Regulation as far as scope and definitions are concerned.

${ }^{40}$ It should be noted that those definitions are not always in compliance with EU law requirements, regardless of the legal duty of Member States. Also, vague requirements, such as in the example of mixed-purpose transactions, may lead to considerable divergence among Member States.

${ }^{41}$ Some countries may for example implement Directive 2011/83/EU into their Civil Codes, other may implement it into other more specific acts, and still others may issue a new act that will include the provisions of this Directive.

${ }^{42}$ Treaty on Functioning of the European Union [2010] OJ C 83/47.

${ }^{43}$ See (n 39).
} 
entrepreneurs, as well as trust towards legal procedures that will be identical in every Member State.

Secondly, the concurrent use of a directive that still remains the "primary act" and a regulation that plays a complementary role is less radical than the use of a regulation alone, and therefore may be more acceptable at the political level as well as in light of the subsidiarity principle. Moreover, this mixed system gives EU lawmakers the flexibility to decide (without prejudice to Treaty rules) which issues are captured by a regulation and which can be left for a directive.

\section{CONCLUSIONS}

European integration cannot proceed properly without attention paid to linguistic issues. The European Union continues to expand, and as a result many more official languages are being added to an already substantial collection. As mentioned earlier, more languages mean more translations and more translations mean more staff and a more profound impact of interpretation on the law. It also means susceptibility to mistakes and divergence during the implementation process. It shows that a European language policy and time for the development of terminology are required. At present, the official legal language of the European Union is far from being a common pan-European standard $^{44}$. If the practice of including document-specific definitions in directives, databases, and dictionaries is continued as the only means of achieving common understanding, the process of developing this common understanding may be very slow, if not impossible to achieve. This thesis finds support in the fact that different initiatives aimed at boosting convergence within the internal consumer market accompanying legislative activity have been proposed. One of them is the European Commission's proposal of the "blue button". By clicking on this button the consumer was supposed to be able to make a purchase under European Common Frame of Reference (CFR) laws rather than under national consumer legislation ${ }^{45}$. However, the project proved to be unsuccessful due to the fact that participation in the blue button initiative was voluntary for suppliers.

The law itself can be compared to a living organism, as it is constantly developing and changing; not every term will apply to the same concept forever. This implies that legal language must evolve as well. It must also be kept in mind that, just like every other language, legal language is an instrument

44 Barbara Pozzo, 'Harmonisation of European Contract Law and the Need of Creating a Common Terminology' (2003) 11 European Review of Private Law 754.

$45<$ http://www.presseurop.eu/en/content/news-brief/344591-eu-button-free-online-trade $>$ accessed 10 August 2013. 
to help people understand one another. For this reason proper language policy may not be enough in terms of full harmonization of consumer law, as translations and the use of definitions from national codes may lead to language divergence. Also, differences in legal culture (in respect of both society and the legal profession) in different Member States may increase the gap. Therefore, in my opinion, the use of regulations as tools supporting directives, as in the case of the Market Abuse Directive revision, is the best way to achieve full harmonization. Even though this solution may seem to be radical, it will boost the speed of convergence processes and ensure that a common system ensuring trust is developed.

As far as transactions themselves are concerned, the issue of language divergence is easier to resolve. First of all, EU lawmakers should focus on building a good framework for entrepreneurs to encourage them to engage in cross-border online sales. One way to achieve this goal is to standardize the procedure for online sales as was done with the model withdrawal form. However, this must be carefully balanced, as too much standardization can cause higher transaction costs and therefore make this kind of selling less competitive in comparison to traditional sales. In my opinion, other language problems connected with the cross-border online sales will be naturally resolved by the market as, for example, in the case of Polish banks with online accounts, for which the electronic signature turned out to be a fiasco ${ }^{46}$. Assuming that it is profitable for them to do so, web pages of enterprises will be translated into English, and they will focus more on visual means of information rather than on textual ones. It must be remembered that the market is much more flexible than the legislative process, which takes time. For this reason the law should balance protection of consumers that ensures trust of customers in cross-border transactions with $t$ the need to prevent high transactions costs discouraging business. The rest can be left to the market itself. Directive 2011/83/EU seems to fulfil the demands of this postulate, but whether it will be successful depends on its proper implementation into Member States' legal systems, which again returns us to the problem of legal language.

${ }^{46}$ Ireneusz Pszczółka, 'Wirtualne banki' (2001) 3 Enter. 